\title{
New record of mangrove lichens from Andhra Pradesh and Orissa states of India
}

\section{Vinay Bharadwaj $\mathrm{T}^{*}$}

KL College of Pharmacy, Koneru Lakshmaiah Education Foundation, Vaddeswaram - 522 502, Guntur, Andhra Pradesh, India

Vinay Bharadwaj T 2019 - New record of mangrove lichens from Andhra Pradesh and Orissa states of India. Studies in Fungi 4(1), 97-100, Doi 10.5943/sif/4/1/12

\begin{abstract}
Two manglicolous lichen species namely, Graphis ajarekarii Patw. and C. R. Kulk on the twigs of Avicennia officinalis from Nagayalanka lighthouse of Krishna estuary, Andhra Pradesh and Ramalina leiodea (Nyl.) Nyl. on the twigs of Ceriops decandra from Bhitarkanika island of Mahanadi estuary, Orissa state are reported. Both the species are new records on the mangroves of Andhra Pradesh and Orissa states of India.
\end{abstract}

Key words - estuaries - Graphis ajarekarii - manglicolous lichens - Ramalina leiodea

\section{Introduction}

Mangroves consist of a unique ecological environment that host rich assemblage of species (Tomlinson 1987). The muddy and loose sediments attract rich epifloral communities including fungi, macroalgae, bacteria and invertebrates, for instance, lichen is one such organism (Tomlinson 1987, Sastry \& Bharadwaj, 2018). The aerial roots, trunks and branches host other group of organisms and contribute to its unique characteristics (Sastry \& Bharadwaj, 2018, Kathiresan \& Bingham 2001). Even though, mangroves are abode for unique species like lichens, they received very poor attention (Awasthi 2007, Mohan \& Hariharan 2000, Logesh 2011, Jagadeesh et al. 2012, Bharadwaj et al. 2018). Up-to-date, there were no proper records on the occurrence of lichens on the mangrove forests of Andhra Pradesh and Orissa states of India (Awasthi 2007, Panda et al. 2017).

A symbiosis between mycobiont (fungus) and a photobiont (algal) or a cyanobiont (cyanobacterium) is named as a Lichen, where the mycobiont provide the shape and the structure while the photobiont or cyanobiont supply food i.e. carbohydrates (Bharadwaj et al. 2018). Lichens are epiphytes that are found attached to plant surfaces, rocks and dead logs (Jagadeesh et al. 2012). Depending on the thallus structure (vegetative body), lichens are mainly categorized into three forms namely fructose, foliose and crustose (Awasthi 2007). In particular, lichens that found on mangroves are termed as manglicolous lichens. Earlier field works on mangroves of Sudarban and Muthupet mangroves, India reported around 142 and 8 manglicolous lichen species, respectively (Awasthi 2007, Logesh et al. 2012, Panda et al. 2017). Besides, there were no detail studies of manglicolous lichens in other parts of India. In continuation of our quest for chemical and pharmacological evaluation of manglicolous lichens in Andhra Pradesh and Orissa states of India, we have identified two new records of mangrove lichens, which were reported in this paper. 


\section{Materials \& Methods}

The morphology and anatomy features are examined by using dissecting and Olympus BX-50 compound microscopes and compared with recent literature available on lichen taxonomy. In addition, chemical analysis was performed by thin layer chromatography and colour spot tests (Orange et al. 2010). The entire data was encrypted in herbariums which were deposited in the Lichen Herbarium of the Council of Scientific and Industrial Research-National Botanical Research Institute (CSIR-NBRI), Lucknow (LWG), India.

Table 1 Details of manglicolous lichens along with their location coordinates and elevation.

\begin{tabular}{|l|l|l|l|l|l|}
\hline $\begin{array}{l}\text { S. } \\
\text { No }\end{array}$ & $\begin{array}{l}\text { Manglicolous } \\
\text { Lichen Species }\end{array}$ & $\begin{array}{l}\text { Host } \\
\text { species }\end{array}$ & Place & Coordinates & Elevation \\
\hline 1 & $\begin{array}{l}\text { Graphis ajarekarii } \\
\text { Patw. \& C. R. Kulk }\end{array}$ & $\begin{array}{l}\text { Avicennia } \\
\text { officinalis }\end{array}$ & $\begin{array}{l}\text { About 15 km (towards east) } \\
\text { from Gullalamodha village } \\
\text { towards Nagayalanka } \\
\text { lighthouse, Krishna estuary, } \\
\text { Andhra Pradesh, India }\end{array}$ & $\begin{array}{l}20^{\circ} 73^{\prime} 70^{\prime \prime} \mathrm{N} \\
\text { and } \\
86^{\circ} 86^{\prime} 91^{\prime \prime} \mathrm{E}\end{array}$ & $0 \mathrm{~m}$ \\
\hline 2 & $\begin{array}{l}\text { Ramalina leiodea } \\
\text { (Nyl.) Nyl. }\end{array}$ & $\begin{array}{l}\text { Ceriops } \\
\text { decandra }\end{array}$ & $\begin{array}{l}\text { About 200 m (towards west) } \\
\text { from the banks of Mahanadi } \\
\text { estuary into the } \\
\text { Bhitharkanika Island, } \\
\text { Rajnagar, Orissa, India }\end{array}$ & $\begin{array}{l}15^{\circ} 77^{\prime} 34^{\prime \prime} \mathrm{N} \\
\text { and } \\
80^{\circ} 96^{\prime} 29^{\prime \prime} \mathrm{E}\end{array}$ & $10 \mathrm{~m}$ \\
\hline
\end{tabular}

\section{Results}

Graphis ajarekarii Patw. \& C. R. Kulk,

Figs 1A, 2A

Facesoffungi number: FOF342073

三 Graphis ajarekarii Patw. \& C. R. Kulk. Norwegian Journal of Botany 26: 45, 1979 (Graphidaceae).

Lichen specimen collected on twigs of Avicennia officinalis at India, Andhra Pradesh,

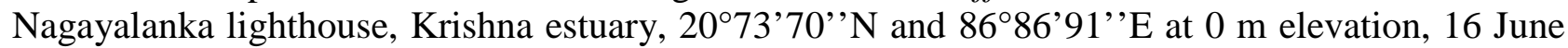
2015, (collector) Vinay Bharadwaj T, herbarium number: 15-027174, Material examined and deposited at India, Lucknow, CSIR-NBRI, Lichenology Laboratory.

Description: Life habit: lichenized; thallus lirellae elongated and irregularly branched. Upper surface black. Medulla white. Lower surface grey with thin cortex. Cortex: 12-22 $\mu \mathrm{m}$ thick. Apothecia absent. Ascomata lirelliform. Ascospores: 15-45 × 8-9.5 $\mu \mathrm{m}$. Hymenium indistinct.

Chemistry: thallus $\mathrm{K}+$ yellow, $\mathrm{P}+$ orange

Ramalina leiodea (Nyl.) Nyl.,

Figs 1B, 2B

Facesoffungi number: FOF403762

三 Ramalina subfraxinea subsp. leiodea Nyl. Bulletin de la Société Linnéenne de Normandie 4: 141, 1870 (Ramalinaceae).

Lichen specimen collected on twigs of Ceriops decandra at India, Orissa, Mahanadi estuary,

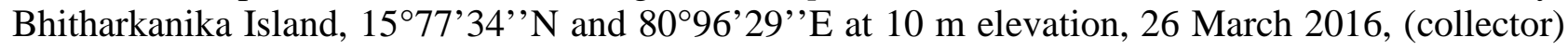
Vinay Bharadwaj T, herbarium number: 16-027175, Material examined and deposited at India, Lucknow, CSIR-NBRI, Lichenology Laboratory.

Description: Life habit: lichenized; thallus: corticolous, up to $15-20 \mathrm{~cm}$ tall. Lobe Surface: grey-green. Medulla: white, laxly arachnoid. Ascomata apothecial, $5.5-11 \mathrm{~mm}$ in diameter. Apothecia: marginal and subteminal, disc 2-3.5 mm diameter. Ascospores: 11-17 × 4.5-6 $\mu \mathrm{m}$. Cortex: thick walled hyphae running transversely or irregularly, up to $22 \mu \mathrm{m}$ thick, chondroid strand. 
Chemistry: Major - boninic acid, 2-O-methylsekikaic acid. Minor - 2,4'-di-Omethylnorsekikaic acid, 4'-O-methylpaludosic acid, 4,4'-di-O-methylcryptochlorophaeic acid. Medulla K-.
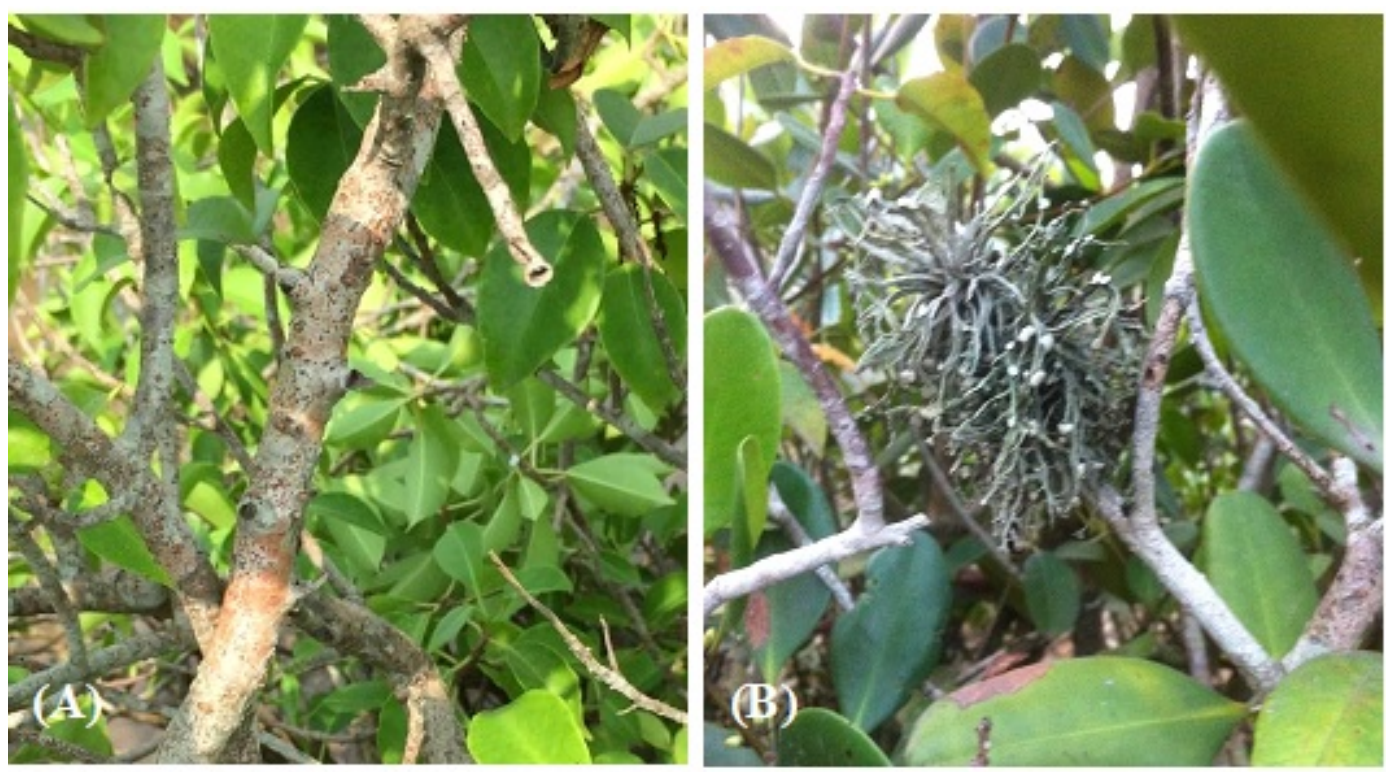

Fig. 1 - Images of A Graphis ajarekarii Patw. \& C. R. Kulk. B Ramalina leiodea (Nyl.) Nyl. Scale Bars: $A, B=1 \mathrm{~cm}$.
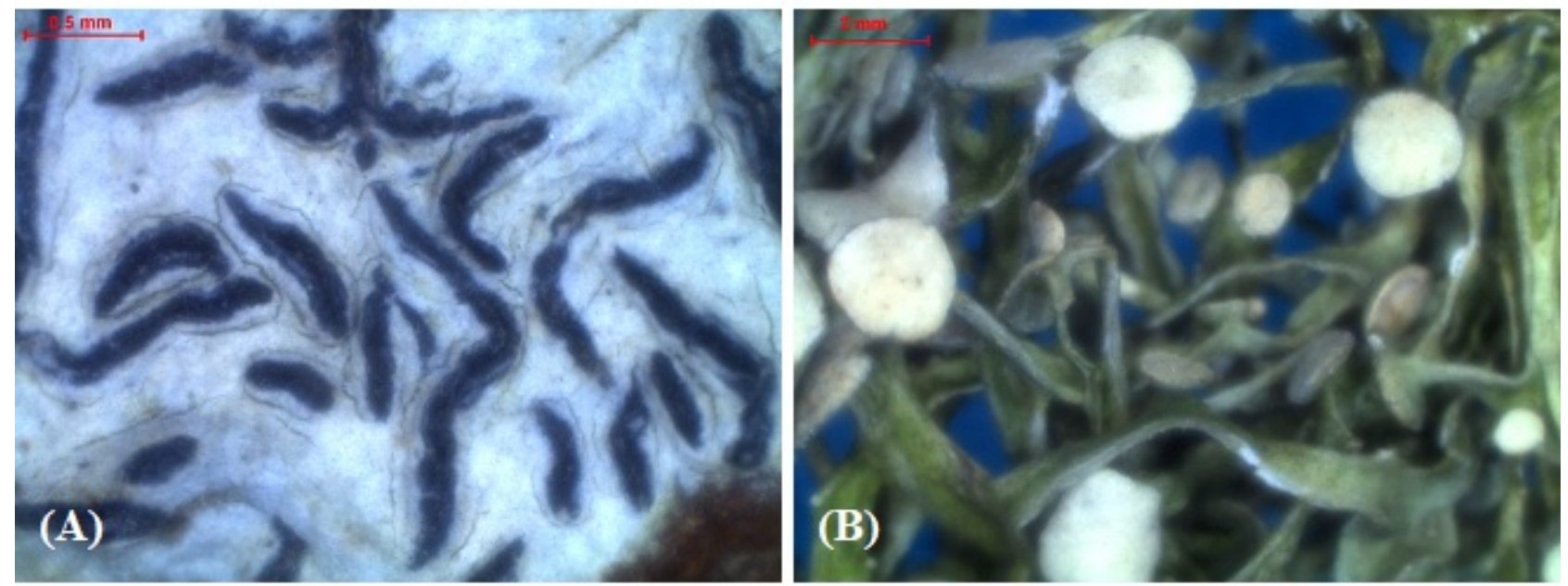

Fig. 2 - Microscopic images of A Graphis ajarekarii Patw. \& C. R. Kulk. B Ramalina leiodea (Nyl.) Nyl. Scale bars: A $=0.5 \mathrm{~mm}, \mathrm{~B}=2 \mathrm{~mm}$.

\section{Acknowledgements}

We thank Dr. D. K. Upreti, Lichenologist, CSIR-NBRI, Lucknow for identification and storage of specimens.

\section{References}

Awasthi DD. 2007 - A compendium of the macrolichen from India, Nepal and Sri Lanka. Bishen Singh Mahendra Ral Singh, Dehra Dun, India.

Bharadwaj VT, Sastry GV, Murthy KS. 2018 - A note on the occurrence of lichens on Vainateya Godavari mangroves in East Godavari district of Andhra Pradesh India. Studies in Fungi, 3, 302-308 
Jagadeesh RTAM, Sinha GP, Singh KP. 2012 - Lichen flora of Sundarbans Biosphere Reserve, West Bengal. Dishen Sigh Mahendra Pal Shingh, Dehra Dun. pp: 384.

Kathiresan K, Bingham BL. 2001 - Biology of mangroves and mangrove ecosystems. Advances in Marine biology, 40, 81-251.

Logesh AR. 2011 - Mangroves: an abode for unique lichens. Cocasal Ecosystems of India- Special publication, 1/March 2013, 39-44.

Logesh AR, Upreti DK, Kalaiselvam M, Nayaka S, Kathiresan. 2012 - Lichen flora of Pichavaram and Muthupet mangroves (Southeast Coast of India). Mycosphere (DOI: 10.5943/mycosphere/3/6/1)

Mohan MS, Hariharan GN. 2000 - Lichen distribution pattern in Pichavaram - A preliminary study to indicate forest disturbance in the mangroves of South India. In: Biology of Lichens. Mukerji KG, Charmola BP, Upreti DK and Upadhyay RK (eds.), Aravali Books International, New Delhi, India, pp: 283-296.

Orange E, Lumbsch HT, Elix JA. 2010 - Microchemical methods for the identification of lichen substances, (II eds.), British Lichen Society, London, pp. 475-479.

Panda M, Murthy TVR, Samal RN, Lele N et al. 2017 - A comparative study of manglicolous lichens and their distribution inside Bhitarkanika National Park (Odisha), India. Studies in Fungi, 2(1), 1-13.

Sastry GV, Bharadwaj VT. 2018 - Occurrence of mosses in Indian mangrove forest. Journal of Integral Sciences, 1, 1-6.

Tomlinson PB. 1987 - The botany of Mangroves. Bartonia, 53, 58-60. 